\title{
Pengaruh Model Pembelajaran Kooperatif Tipe Rotating Trio Exchange (RTE) terhadap Hasil Belajar Fisika Kelas XI SMA Negeri 1 Palu
}

\author{
Rai Agustini, Yusuf Kendek, dan Kamaluddin \\ rayagustini2017@gmail.com \\ Program Studi Pendidikan Fisika FKIP Universitas Tadulako \\ Jl. Soekarno Hatta Km. 9 Kampus Bumi Tadulako Tondo Palu - Sulawesi Tengah
}

\begin{abstract}
Abstrak -Tujuan penelitian ini adalah untukmengetahui adanya pengaruh model pembelajaran kooperatif tipe Rotating Trio Exchange (RTE) terhadap hasil belajar fisika kelas XI SMA Negeri 1 Palu. Metode yang digunakan adalah eksperimen kuasi dengan the equivalent pretest-posttest design. Populasi penelitian ini adalah seluruh siswa kelas XI IPA SMA Negeri 1 Palu.Teknik pengambilan sampel adalah purposive sampling. Kelas XI IPA 2 sebagai kelas eksperimen, dan kelas XI IPA 3 sebagai kelas kontrol.Instrumen hasil belajar berupa tes berbentuk pilihan gandayang berjumlah 23 soal dan telah divalidasi. Skor rata-rata kelas yang menggunakan model pembelajaran kooperatif tipe rotating trio exchangesebesar 90.06 dengan standar deviasi sebesar 8,08, sedangkan skor rata-rata yang diperoleh pada kelas kontrol sebesar 84,03 dengan standar deviasi sebesar 7,81. Pengujian data hasil belajar menggunakan uji-t dua pihak pada taraf signifikansi 0,05 dan dk = 64, dengan uji prasyarat normalitas dan homogenitas. Hasil perhitungan statistik diperoleh harga thitung sebesar 3,08 dan $t_{\text {tabel }}$ pada taraf signifikansi 0,05 dan $\mathrm{dk}=64$ adalah 1,98. Hasil analisis menunjukkan bahwa terdapat perbedaan hasil belajar antara siswa yang mengikuti model pembelajaran kooperatif tipe Rotating Trio Exchange (RTE) dengan siswa yang mengikuti model pembelajaran konvensional.Sehingga dapat disimpulkan bahwa terdapat pengaruh model pembelajaran kooperatif tipe Rotating Trio Exchange terhadap hasil belajar fisika kelas XI SMA Negeri 1 Palu.
\end{abstract}

Kata Kunci: rotating trio exchange, hasil belajar, kelas XI

\section{PENDAHULUAN}

Belajar merupakan hal yang sangat mendasar yang tidak bisa lepas dari kehidupan manusia.Seiring dengan perkembangan masyarakat dan kebutuhan yang meningkat, pemerintah berupaya untuk meningkatkan mutu dunia pendidikan. Hal yang harus dilakukan dunia pendidikan ternyata harus mempersiapkan sumber daya manusia yang kreatif, mampu memecahkan persoalanpersoalan yang aktual dalam kehidupan dan mampu menghasilkan teknologi baru yang merupakan perbaikan dari sebelumnya [1].

Pelajaran fisika yang merupakan salah satu bidang keilmuan yang menuntut adanya kemampuan dalam mengkontruksi, memahami dan memberikan pengalaman langsung pada siswa agar dapat memberikan hasil belajar yang baik. Kenyataan ini hendaknya diikuti dengan adanya pembelajaran fisika yang sesuai dan memadai.Sudah tidak asing lagi bahwa mata pelajaran fisika di Indonesia merupakan pelajaran yang sulit, berat dan tidak disenangi sehingga pada akhirnya dapat menurunkan daya minat siswa untuk mempelajarinya terutama pada tingkatan SMP dan SMA.

Salah satu usaha yang dapat dilakukan untuk memperbaiki keadaan tersebut adalah dengan menggunakan model pembelajaran kooperatif. Pembelajaran kooperatif adalah suatu model pembelajaran dimana siswa belajar dan bekerja dalam kelompok-kelompok kecil secara kolaboratif dengan struktur kelompok heterogen. Untuk mendapatkan hasil yang optimal dalam proses pembelajaran aktif, maka pada penelitian ini peneliti akan menggunakan model pembelajaran kooperatif. Alasan dipilihnya model pembelajaran kooperatif yaitu karena akan melatih peserta didik untuk bertanggung jawab, bekerjasama serta banyak membantu siswa dalam pemahaman materi pembelajaran khususnya mata pelajaran fisika [2].

Salah satu cara untuk menjadikan peserta didik aktif dari awal adalah dengan menggunakan strategi Rotating Trio Exchange. Strategi ini dirancang untuk memperkenalkan peserta didik terhadap mata pelajaran fisika guna membangun minat, menimbulkan rasa ingin tahu dan merangsang mereka untuk berpikir serta mampu meningkatkan sikap percaya diri. Rotating Trio Exchange adalah strategi pembelajaran aktif yang digunakan untuk mendiskusikan permasalahan bersama teman sekelas. Rotating Trio Exchange ini sering disebut dengan merotasi pertukaran pendapat kelompok tiga orang. 
p-ISSN 2338-3240, e-ISSN 2580-5924

Perpindahan kelompok pada model pembelajaran kooperatif tipe Rotating Trio Exchange dilakukan pada setiap pergantian pertanyaan yang terdapat pada LKS setelah selesai melakukan praktikum sehingga siswa tidak hanya bekerja pada suatu kelompok saja, namun siswa bekerja pada kelompok yang berganti-ganti. Dengan demikian, siswa tidak hanya mengandalkan anggota kelompoknya saja, tetapi ikut berusaha demi keberhasilan kelompoknya. Setiap siswa menyadari tanggung jawab dalam kelompoknya sehingga siswa menjadi termotivasi untuk mengikuti proses pembelajaran dengan baik. Selain itu, pada saat presentasi hasil praktikum setiap siswa yang berbicara (bertanya, menjawab, dan menanggapi) akan dinilai oleh guru. Hal ini berarti seluruh siswa ikut terlibat aktif dan termotivasi dalam pembelajaran karena siswa memberikan pertanyaan kepada kelompok lain, siswa yang menanggapi ataupun menjawab pertanyaan. Siswa saling berinteraksi membandingkan jawaban mereka, dan mengoreksi hal - hal yang kurang tepat dan saling berdiskusi memahami pelajaransehingga siswa akan memiliki suatu pengetahuan atau pemahaman yang baik. Oleh karena itu, model ini sangat cocok diterapkan pada mata pelajaran fisika [3].

Berdasarkan latar belakang di atas, peneliti tertarik untuk memadukan pembelajaran kooperatif dengan tipe Rotating Trio Exchange.Adapun perbedaan penelitian ini terhadap penelitian yang sebelumnya yaitu dalam penelitian ini rotasi yang dilakukan sebanyak empat kali dan setelah semua pertanyaan selesai, maka siswa kembali ke kelompok awal untuk mendiskusikan jawaban yang diperoleh masing-masing anggota kelompok untuk dipresentasikan di depan kelas.Oleh karena itu diadakan penelitian dengan judul Pengaruh Model Pembelajaran Kooperatif Tipe Rotating Trio Exchange (RTE) Terhadap Hasil Belajar Fisika Kelas XI SMA Negeri 1 Palu.

\section{METODE PENELITIAN}

Jenis penelitian ini adalah penelitian eksperimen semu atau quasi eksperimen dengan desain rancangan prates-pascates yang ekuivalen [4] (the equivalen, Pretest-Posttest Design) seperti Tabel 1.
TABEL 1 DESAIN PENELITIAN

\begin{tabular}{lccc}
\hline Kelompok & Pretest & Perlakuan & Posttest \\
\hline $\mathrm{KE}$ & $\mathrm{O}_{1}$ & $\mathrm{X}_{1}$ & $\mathrm{O}_{2}$ \\
$\mathrm{KK}$ & $\mathrm{O}_{1}$ & - & $\mathrm{O}_{2}$
\end{tabular}

Keterangan:

KE : Kelas eksperimen

$\mathrm{KK}$ : Kelas kontrol

$\mathrm{X}_{1}$ : Perlakuan untuk kelas eksperimen dengan penggunakan model Pembelajaran kooperatif tipe Rotating Trio Exchange (RTE).

$\mathrm{O}_{1}$ : Tes awal untuk kelas eksperimen dan kelas kontrol

$\mathrm{O}_{2}$ : Tes akhir untuk kelas eksperimen dan kelas kontrol

Populasi dalam penelitian ini adalah seluruh siswa kelas XI IPA SMA Negeri 1 Palu yang terdaftar tahun ajaran 2016/2017 yang mana kelas XI IPA terdiri dari 8 kelas. Pemilihan sampel dilakukan dengan teknik purposive sampling, yaitu pemilihan kelas yang didasarkan pada pertimbangan tertentu, dimana dua kelas yang akan dijadikan sampel penelitian adalah kelas yang berdasarkan hasil pretest memiliki nilai yang homogen. Sehingga berdasarkan pertimbangan tersebut, maka diambil dua kelas sebagai sampel penelitian, yaitu kelas yang terpilih adalah XI IPA 2 sebagai kelas eksperimen yang mengikuti pembelajaran dengan model pembelajaran Kooperatif Tipe Rotating Trio Exchange dan kelas XI IPA 3 sebagai kelas kontrol yang mengikuti pembelajaran dengan model pembelajaran konvensional.

\section{HASIL DAN PEMBAHASAN}

Dari hasil analisis butir soal dengan menggunakan empat kriteria yaitu validitas, tingkat kesukaran, daya pembeda dan reliabilitas tes diperoleh soal yang memenuhi syarat untuk digunakan sebagai tes hasil belajar berjumlah 23 soal dari 40 soal yang diujikan.

\section{A. Hasil Penelitian}

1. Deskripsi skor pretest

Deskripsi skorpretestkelas eksperimen yang terdiri dari 34 siswa dan kelas kontrol yang terdiri dari 32 siswa, diperoleh rekapitulasi data sebagai berikut:

TABEL 2 DATA HASIL PRETEST

\begin{tabular}{lc} 
No.Distribusi & \multicolumn{1}{c}{ Pretest } \\
\cline { 2 - 2 } Frekuensi & EksperimenKontrol \\
\hline 1Skor Tertinggi5248 & \\
2Skor Terendah2622 & \\
3Skor rata-rata44,1841,03 \\
4Varians66,7669,13 \\
5Standar Deviasi8,178,31 \\
\hline
\end{tabular}


p-ISSN 2338-3240, e-ISSN 2580-5924

Berdasarkan Tabel 2 di atas, menunjukkan hasil pretest kedua kelas.Terlihat bahwa nilai tertinggi yang diperoleh kelas eksperimen adalah sebesar 52, sedangkan kelas kontrol adalah 48. Nilai terendah yang diperoleh kelas eksperimen adalah sebesar 26, sedangkan kelas kontrol adalah 22. Nilai rata-rata yang diperoleh tidak berbeda jauh yatu sebesar 44,18 dan 41,03 . Nilai varians kelas eksperimen 66,76 dan kelas kontrol 69,13 . Untuk standar deviasi kelas eksperimen 8,17 dan kelas kontrol 8,31.

2. Uji Normalitas Data Pretest

Uji normalitas terhadap dua kelas menggunakan uji Chi Kuadrat.Dalampenelitian ini, hasil uji normalitas yang diperoleh disajikan pada Tabel 3.

TABEL 3 UJI NORMALITAS PRETEST KELAS EKSPERIMEN DAN KELAS

\begin{tabular}{cccc}
\multicolumn{2}{c}{ KONTROL } & Nilai $\chi^{2}$ Tabel & \\
\cline { 2 - 3 } Kategori & $\begin{array}{c}\text { Kelas Kelas } \\
(\mathrm{a}=\end{array}$ & Keputusan \\
& eksperimenkontrol & $0,05)$ & \\
\hline Pretest6,347,19 7,81 & & $\begin{array}{c}\text { Terdistribusi } \\
\text { Normal }\end{array}$ \\
\hline
\end{tabular}

Berdasarkan Tabel 3, terlihat bahwa hasil uji normalitas data pretestpada kelas eksperimen maupun kelas kontrol terdistribusi normal. Dimana kriteria pengujian yang digunakan pada derajat kebebasan $\mathrm{dk}=(\mathrm{k}-3)=(6-3)=3$, dan peluang ( 1 - $a$ ) dengan taraf nyata $a=0,05$ dengan kriteria pengujiannya jika $\chi^{2}$ hitung $<\chi^{2}$ tabel.

3. Uji Homogenitas Data Pretest

Setelah kedua kelompok sampel penelitian dinyatakan berdistribusi normal, selanjutnya dicari nilai homogenitas. Uji homogenitas pada penelitian ini menggunakan uji $\mathrm{F}$ dengan taraf signifikansi $a=0,05$. Adapun hasil $u j i$ homogenitas pada kelas eksperimen dan kontrol dilihat pada Tabel 4.

TABEL 4 HASIL UJI HOMOGENITAS PRETEST KELAS EKSPERIMEN DAN

\begin{tabular}{|c|c|c|c|}
\hline Nilai Varians & & Nilai & \\
\hline $\begin{array}{l}\text { Kelas Kelas } \\
\text { eksperimenkontrol }\end{array}$ & $\begin{array}{l}\text { Nilai } \\
\text { FHitung }\end{array}$ & $\begin{array}{l}F_{\text {tabel }} \\
(a= \\
0,05)\end{array}$ & Keputusan \\
\hline $66,7669,131,04$ & & 1,81 & $\begin{array}{c}\text { Kedua Data } \\
\text { Homogen }\end{array}$ \\
\hline
\end{tabular}

Berdasarkan Tabel 4, terlihat bahwa hasil uji homogenitas data pretest pada kelas eksperimen maupun kelas kontrol adalah homogen. Dimana kriteria penerimaan jika Fhitung $<\mathrm{F}_{\text {tabel }}$.

4. Uji-t Data Pretest

Berdasarkan uji prasyarat analisis statistik diperoleh bahwa data pretest terdistribusi normal dan homogen, sehingga pengujian hipotesis yang digunakan adalah uji-t (uji dua pihak).

TABEL 5 HASIL UJI HIPOTESIS (PRETEST) KELAS EKSPERIMEN DAN KELAS KONTROL

$\frac{\text { KONTROL }}{\text { Skor rata-rata } \bar{X}}$ t Hitungt tableKeputusan

$44,1841,031,551,98 \mathrm{H}_{0}$ diterima

Pada Tabel5 terlihat bahwa skor rata-rata pada kelas eksperimen adalah 44,18 sedangkan pada kelas kontrol adalah 41,03. Secara sepintas skor rata-rata yang diperoleh memang berbeda, akan tetapi berdasarkan ujit diperoleh nilai thitung sebesar 1,55 dan nilai tabel pada taraf signifikan $(a=0,05)$ sebesar 1,98. Hasil pengujian yang diperoleh menunjukkan bahwa thitung berada pada daerah penerimaan $\mathrm{H}_{0}$, yaitu $t_{\text {hitung }}<$ tabel.Dengan demikian $\mathrm{H}_{0}$ diterima dan $\mathrm{H}_{1}$ ditolak. Hal ini menunjukkan bahwa data yang diperoleh pada saat pretest tidak terdapat perbedaan hasil belajar pada kelas eksperimen maupun kelas kontrol.

\section{Deskripsi Skor Posttest}

Deskripsi skor Posttestkelas eksperimen yang terdiri dari 34 siswa dan kelas kontrol yang terdiri dari 32 siswa, diperoleh rekapitulasi data sebagai berikut:

TABEL 6 DATA HASIL PRETEST DAN POSTTEST

\begin{tabular}{llcc}
\hline \multirow{2}{*}{ No. } & Distribusi & \multicolumn{2}{c}{ Posttest } \\
\cline { 2 - 4 } & Frekuensi & 100 & 91 \\
\hline 1 & Skor Tertinggi & 74 & 65 \\
2 & Skor Terendah & 90,06 & 84,03 \\
3 & Skor rata-rata & 65,33 & 61,06 \\
4 & Varians & 8,08 & 7,81 \\
5 & Standar Deviasi & & Kontrol \\
\hline
\end{tabular}

Tabel 6 di atas memperlihatkan hasil posttestdengan nilai tertinggi yang diperoleh kelas eksperimen adalah sebesar 100, sedangkan kelas kontrol 91. Nilai terendah yang diperoleh kelas eksperimen adalah sebesar 74, sedangkan kelas kontrol adalah sebesar 65 . Nilai rata-rata yang diperoleh pada kelas eksperimen sebesar 90,06 dan kelas kontrol sebesar 84,03 . Nilai varians kelas eksperimen 65,33 dan kelas kontrol 61,06 . Untuk standar deviasi kelas eksperimen 8,08dan kelas kontrol 7,81 .

6. Uji Normalitas Posttest

Uji normalitas terhadap dua kelas menggunakan uji Chi Kuadrat. Dalam penelitian ini, hasil uji normalitas yang diperoleh disajikan pada Tabel 7. 
TABEL 7 HASIL UJI NORMALITAS POSTTEST KELAS EKSPERIMEN DAN

\begin{tabular}{|c|c|c|c|c|}
\hline \multirow[b]{2}{*}{ Kategori } & \multicolumn{2}{|c|}{ Nilai $\chi^{2}$ Hitung } & \multirow{2}{*}{$\begin{array}{c}\text { Nilai } \\
\chi^{2} \text { Tabel } \\
(a= \\
0,05)\end{array}$} & \multirow[b]{2}{*}{ Keputusan } \\
\hline & $\begin{array}{l}\text { Kelas } \\
\text { eksperimen }\end{array}$ & $\begin{array}{l}\text { Kelas } \\
\text { kontrol }\end{array}$ & & \\
\hline \multicolumn{3}{|c|}{ Posttest7,047,11 } & 7,81 & $\begin{array}{c}\text { Terdistribusi } \\
\text { Normal }\end{array}$ \\
\hline
\end{tabular}

Berdasarkan Tabel 7, terlihat bahwa hasil uji normalitas data posttest pada kelas eksperimen maupun kelas kontrol terdistribusi normal. Dimana kriteria pengujian yang digunakan pada derajat kebebasan $\mathrm{dk}=(\mathrm{k}-3)$ $=(6-3)=3$, dan peluang $(1-a)$ dengan taraf nyata $a=0,05$ dengan kriteria pengujiannya jika $\chi^{2}$ hitung $<\chi^{2}$ tabel.

7. Uji Homogenitas Data Posttest

Setelah kedua kelompok sampel penelitian dinyatakan berdistribusi normal, selanjutnya dicari nilai homogenitas. Uji homogenitas pada penelitian ini menggunakan uji $\mathrm{F}$ dengan taraf signifikansi $a=0,05$. Adapun hasil uji homogenitas data posttest pada kelas eksperimen dan kontrol dilihat pada Tabel 8.

TABEL 8 HASIL UJI HOMOGENITAS POSTTEST KELAS EKSPERIMEN DAN

\begin{tabular}{lccc}
\multicolumn{1}{c}{ KELAS KONTROL } & Nilai & Nilai & Keputusan \\
\cline { 1 - 3 } $\begin{array}{l}\text { Kelas Kelas } \\
\text { eksperimenkontrol }\end{array}$ & $\begin{array}{c}F_{\text {tabel }} \\
(\mathrm{a}= \\
0,05)\end{array}$ & \\
\hline $65,3361,061,07$ & 1,81 & $\begin{array}{c}\text { Kedua Data } \\
\text { Homogen }\end{array}$ \\
\hline
\end{tabular}

Dari Tabel 8, terlihat bahwa hasil uji homogenitas dataposttest pada kelas eksperimen maupun kelas kontrol adalah homogen. Dimana kriteria penerimaan jika Fhitung $<$ Ftabel.

\section{Uji-t Data Posttest}

Berdasarkan uji prasyarat analisis statistik diperoleh bahwa data posttestterdistribusi normal dan homogen, sehingga pengujian hipotesis yang digunakan adalah uji-t (uji dua pihak).

TABEL 9 HASIL UJI HIPOTESIS (POSTTEST)KELAS EKSPERIMEN DAN KELAS KONTROL

Nilai rata-rata $\bar{X}$
KelasKelas
eksperimenkontrol $\mathrm{t}_{\text {Hitungt tableKeputusan }}$

$90,0684,033,081,98 \mathrm{H}_{1}$ diterima

Pada Tabel 9 terlihat bahwa nilai thitung sebesar 3,08 dan nilai tabel pada taraf signifikan $(a=0,05)$ sebesar 1,98. Hasil pengujian yang diperoleh menunjukkan bahwa thitung berada pada daerah penerimaan $\mathrm{H}_{1}$, yaitu

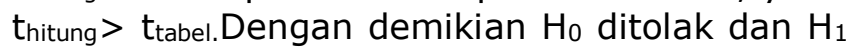
diterima. Hal ini menunjukkan bahwa terdapatperbedaan hasil belajar antara siswa yang mengikuti model pembelajaran kooperatif tipe Rotating Trio Exchange (RTE) dengan siswa yang mengikuti model pembelajaran konvensional.Sehingga dapat disimpulkan bahwa terdapat pengaruh model pembelajaran kooperatif tipe Rotating Trio Exchange (RTE) terhadap hasil belajar fisika siswa di Kelas XI IPA SMA Negeri 1 Palu.

Hasil perolehan skor rata-rata posttest untuk kelas eksperimen adalah sebesar 90,06 sedangkan skor rata-rata yang diperoleh pada kelas kontrol sebesar 84,03. Hal ini membuktikan bahwa terdapat perbedaan hasil belajar yang signifikan dari siswa yang mengggunakan model pembelajaran kooperatif tipe rotating trio exchange dengan siswa yang menggunakan model pembelajaran konvensional.

Selama proses pembelajaran kooperatif tipe rotating trio exchange berlangsung menunjukkan peningkatan hasil belajar siswa, adapun fase-fase pembelajarannya sebagai berikut: 1) Guru melakukan demonstrasi dengan mencelupkan kelereng yang dibungkus selotip (A), batu yang dibungkus selotip (B) dan bola plastik yang dibungkus selotip (C) ke dalam air, kemudian mengajukan pertanyaan "mengapa benda C tidak tenggelam?" terlihat siswa sangat antusias untuk menjawab pertanyaan tersebut; 2) Guru membimbing peserta didik dalam pembentukan kelompok yang terdiri dari 3 orang yang masing-masing diberi simbol 0, 1 dan 2, kemudian siswa langsung membentuk kelompok dan mengatur ruang kelas menyerupai huruf $U$; 3) Guru menyampaikan materi tentang Hukum Archimedes; 4) Guru membagikan LKS pada masing-masing kelompok; 5) Guru memberikan sebuah pertanyaan yang membantu peserta didik untuk memulai diskusi (terdapat pada LKS); 6) Setelah waktu diskusi selesai, peserta didik yang mempunyai simbol 1 berpindah searah jarum jam dan simbol 2 berlawanan jarum jam sedangkan nomor 0 tetap ditempat; 7) Guru memberikan pertanyaan baru untuk didiskusikan oleh trio baru tersebut; 8) Guru melakukan rotasi kembali setelah setiap pertanyaan dijawab; 9) Perwakilan kelompok mempresentasikan hasil diskusi kelompok; 10) Guru memberikan kesempatan kepada kelompok lain untuk memberikan pertanyaan; 11) Guru memberikan tes evaluasi yang dikerjakan secara perorangan; 12) Siswa menyimpulkan tentang materi yang telah dipelajari; dan 13) 
Guru memberikan penghargaan kepada kelompok yang memiliki kinerja dan kerjasama yang baik. Sedangkan pada kelas kontrol yang menerapkan model pembelajaran konvensional fase-fase pembelajarannya sebagai berikut: 1) Guru menjelaskan materi mengenai Hukum Archimedes; 2) Guru memberikan kesempatan kepada siswa untuk bertanya apabila terdapat hal-hal yang belum dipahami mengenai materi Hukum Archimedes; 3) Guru memberikan contoh soal dan penyelesaiannya berkaitan dengan materi Hukum Archimedes; 4) Guru memberikan latihan soal mandiri kepada siswa untuk mengetahui tingkat pemahaman siswa; 5) Guru menunjuk salah satu siswa maju kedepan kelas untuk menyelesaikan soal yang diberikan; 6) Guru meminta kepada siswa lain untuk menanggapi jawaban siswa yang menyelesaikan soal di depan kelas; 7) Guru memberikan kesempatan kembali kepada siswa untuk bertanya terkait materi dan soal yang belum dimengerti; 8) Guru menjawab pertanyaan yang diajukan oleh siswa (jika ada); 9) Guru membimbing siswa untuk menyimpulkan materi yang telah dipelajari; 10) Guru memberikan pekerjaan rumah kepada siswa; dan 11)Guru menutup pelajaran [5].

Berdasarkan fase-fase tersebut, menunjukkan bahwa model pembelajaran kooperatif tipe Rotating Trio Exchange lebih efektif digunakan dibandingkan model pembelajaran konvensional dimana model pembelajaran konvensional lebih berpusat kepada guru sementara pada model kooperatif tipe Rotating Trio Exchange peserta didik dapat berdiskusi secara mendalam dengan beberapa teman dalam kelasnya, kemudian struktur yang jelas dapat memungkinkan peserta didik untuk berbagi dengan pasangan dalam kelompoknya dengan waktu yang teratur. Selain itu, peserta didik mempunyai banyak kesempatan untuk mengolah informasi yang diperoleh.

Penelitian sebelumnya juga membuktikan bahwa penerapan model pembelajaran kooperatif dengan strategi rotating trio exchange dapat meningkatkan hasil belajar siswa [6]. Hasil ini sejalan dengan penelitian yang dilakukan oleh Eplia, dkk yang menyatakan bahwa model pembelajaran ini bukan saja meningkatkan hasil belajar siswa, akan tetapi dengan adanya rotasi siswa dapat mengatasi rasa bosan yang sering dialami siswa dalam kelas [7].

Selain itu, penelitian yang dilakukan oleh Agustyaningrum menyatakan bahwa strategi pembelajaran rotating trio exchange efektif untuk meningkatkan sikap percaya diri peserta didik dan prestasi belajar peserta didik dibandingkan dengan menggunakan pembelajaran konvensional. Dari penelitian tersebut memperlihatkan adanya peningkatan hasil belajar siswa. Berdasarkan penjelasan di atas dan penelitian yang dilakukan, terbukti bahwa terdapat perbedaan hasil belajar antara siswa yang mengikuti model pembelajaran kooperatif tipe rotating trio exchange dengan siswa yang mengikuti model pembelajaran konvensional di kelas XI SMA Negeri 1 Palu. Dengan demikian, terdapat pengaruh model pembelajaran kooperatif tipe rotating trio exchangeterhadap hasil belajar fisika di Kelas XI IPA SMA negeri 1 Palu [8].

\section{KESIMPULAN DAN SARAN}

\section{A. Kesimpulan}

Berdasarkan hasil penelitian dan pembahasan yang diperoleh, maka dapat disimpukan bahwa terdapat pengaruh positif pada penggunaan model pembelajaran kooperatif tipe Rotating Trio Exchange (RTE)terhadap hasil belajar fisika siswa. Hal ini ditunjukkan dengan siswa yang diajarkan dengan model pembelajaran kooperatif tipe Rotating Trio Exchange memiliki skor rata-rata posttest lebih besar dibandingkan dengan skor rata-rata posttest siswa yang diajarkan dengan pembelajaran konvensional. Selain itu, dapat juga dibuktikan dari hasil uji hipotesis dengan thitung sebesar 3,08 dan nilai tabel pada taraf signifikan $(a=0,05)$ sebesar 1,98 maka hipotesis nol $\left(\mathrm{H}_{0}\right)$ di tolak dan hipotesis satu $\left(\mathrm{H}_{1}\right)$ diterima.

B. Saran

Dengan demikian, penulis mengajukan saran yang dapat dijadikan pertimbangan, yaitu guru hendaknya dapat menggunakan model kooperatif tipe Rotating Trio Exchange sebagai alternatif dalam proses belajar mengajar, karena model kooperatif tipe Rotating Trio Exchange berpengaruh positif dalam meningkatkan hasil belajar siswa.

\section{DAFTAR PUSTAKA}

[1] Slameto. Belajar dan faktor-faktor yang mempengaruhinya. Salatiga: Bina Aksar. 1987.

[2] Isjoni. Cooperative Learning Efektivitas Pembelajaran Kelompok. Bandung: Alfabeta, 2010.

[3] F. Wulandari dan A. Alimufi. "Pengaruh model pembelajaran aktif melalui strategi rotating trio exchange terhadap prestasi belajar siswa pada sub pokok bahasan optik geometris kelas viii di smp negeri 30 Surabaya". Jurnal Inovasi Pendidikan Fisika Vol. 02 No. 03 Tahun 2013, 6-10, 2013.

[4] Sugiyono. Metode Penelitian Pendidikan: Pendekatan Kuantitatif, Kualitatif, dan R\&D. Bandung: Penerbit Alfabeta. 2013. 
[5] I. Dyatma. "Pengaruh strategi pembelajaran rotating trio exchange terhadap hasil belajar matematika". Jurnal PGSD Vol: 2 No: 1, 2014.

[6] D. Frensista, D. Trapsilasiwi, dan Nurcholif. Penerapan Model Pembelajaran Kooperatif dengan Strategi Rotating Trio Exchange untuk Meningkatkan Hasil Belajar Siswa Kelas VII A Pada Sub Pokok Bahasan Keliling dan Luas Bangun Segitiga dan Segiempat di SMP Negeri 1 Ajung Semester Genap Tahun Ajaran 2012/2013. FKIP Universitas Jember: tidak diterbitkan. 2013.
[7] M. N. Eplia, A. Thaib, dan Rini. Penerapan Model Kooperatif Tipe Rotating Trio Exchange (RTE) untuk Meningkatkan Prestasi Belajar Siswa pada Pokok Bahasan Tatanama Senyawa dan Persamaan Reaksi di Kelas X IPA SMA Negeri 1 Seberida Kabupaten Indragiri Hulu. FKIP Riau: tidak diterbitkan, 2009.

[8] F. Agustyaningrum. Efektivitas Penerapan Strategi Pembelajaran Rotating Trio Exchange Untuk Meningkatkan Sikap Percaya Diri dan Prestasi Belajar Kelas X SMA N Sedayu Tahun Ajaran 2013-2014. Fakultas Ekonomi UNY: tidak diterbitkan, 2014. 